\title{
RELEVANSI PEMIKIRAN FEMINIS MUSLIM DENGAN FEMINIS BARAT
}

\author{
Dawam Mahfud, Nafatya Nazmi, Nikmatul Maula \\ Universitas Islam Negeri (UIN) Walisongo Semarang \\ e-mail: dawam.mahfud@gmail.com
}

\begin{abstract}
Abstrak
Konstruksi gender dalam masyarakat sangat dipengaruhi oleh agama dan ideologi yang dianutnya, maka wacana teologi gender mulai bergulir. Anggapan bahwa pemahaman agama bias gender membuat arah baru gerakan feminisme, dimana para feminis mulai menawarkan pemaknaan baru terhadap agama sekaligus membongkar dogmadogma agama yang telah mapan dan dianggap membelenggu kaum perempuan. penulis akan membahas tentang apa saja yang diberikan penjelasan relevansi antara pemikiran feminis Islam dengan pemikiran feminis Barat. kedudukan kaum perempuan di Barat sangat terkungkung, baik dalam kehidupan rumah tangga sebagai istri maupun yang berkenaan dengan hak-hak kemasyarakatan. Posisi kaum perempuan pada saat itu tak begitu jauh bedanya dengan kedudukan perbudakan yang diperlakukan semena-mena, pada waktu itulah timbul di benua Eropa gerakan perempuan yang dinamakan gerakan emansipasi. Ketika wacana teologis tentang perempuan dibuka dan menjadi diskursus yang cukup ramai, maka pembahasan dogmadogma agama mulai muncul dan berkembang.
\end{abstract}

Kata Kunci: pemikiran; feminis Muslim; feminis Barat

\section{A. Pendahuluan}

Kemajuan sains dan teknologi yang begitu pesat dewasa ini ternyata tidak dibarengi dengan peningkatan moralitas dan spiritualitas. Fenomena ini dipicu oleh meningkatnya ketidakpedulian dunia, terutama di Barat terhadap ajaran agama dan spiritualitas yang menyebabkan manusia menghadapi berbagai masalah besar dan komplek, salah satu korban utamanya adalah perempuan. Padahal, perempuan sepanjang sejarah menjadi salah satu pilar paling penting bagi berdirinya tonggak keluarga dan masyarakat. Namun lembaran sejarah menunjukkan realitas pahit yang menyesakkan dada tentang kondisi perempuan di era modern. Kini, perempuan menjadi komoditas industri, disaat kaum Feminis dengan lantang menyuarakan 
kesetaraan gender. Semua itu akibat tidak adanya perhatian terhadap posisi dan kedudukan perempuan, terutama di dunia Barat. Sebab posisi perempuan acapkali diturunkan hanya sebagai komoditas kapitalisme maupun pemenuhan kebutuhan biologis laki-laki. Dewasa ini juga hampir setiap produk dari rumah mewah hingga permen memanfaatkan perempuan sebagai alat propaganda media supaya konsumen tertarik dan membelinya. Menurut pemimpin Besar Revolusi Islam Iran, Ayatullah Ali Khumaini, kesalahan paradigma Barat mengenai posisi dan kedudukan perempuan dalam masyarakat karena melihat manusia dalam dua kategori ekstrim, perempuan dan laki-laki. Dunia Barat melihat hubungan laki-laki dan perempuan secara diametral yang saling bertentangan, bukan sebuah posisi yang saling melengkapi dan menyempurnakan. Dalam makalah ini kami mencoba membandingkan dan mengaitkan bagaimana corak pemikiran yang dibangun oleh kaum feminis Barat dan feminis Muslim.

\section{B. Pengertian dan Ruang Lingkup Pemikiran Feminis Muslim}

Kajian mengenai isu gender dalam Islam mengalami perkembangan yang cukup signifikan, hal ini ditandai tidak saja melimpahnya publikasi yang mengangkat wacana gender dan Islam, melainkan juga fakta bahwa ia sudah merambah luas kedalam suatu mainstream gerakan yang kemudian mengundang orang untuk dengan mudah menyebutnya sebagai "gerakan feminisme Islam". Meskipun definisi feminisme Islam itu sendiri masih menjadi perdebatan serius dikalangan aktifis perempuan muslim, pada tingkatan common vision mereka dapat bertemu pada suatu visi misi untuk memperjuangkan keadilan dan kesetaraan gender. ${ }^{1}$

Istilah feminism berasal dari bahasa latin (femina $=$ women), yang berarti memiliki sifat-sifat perempuan. "kata ini dipergunakan untuk menunjukkan kepada suatu teori persamaan kelamin (sexual equality). Feminisme sering didefinisikan dengan pembelaan terhadap hak-hak perempuan yang didasarkan kepada keyakinan akan kesamaan jenis kelamin. Dalam arti luas kata feminism juga menunjukkan kepada setiap orang yang memiliki kesadaran terhadap subordinasi perempuan dan berusaha untuk mengakhirinya dengan berbagai cara dan alasan.

1Jamhari Ismatu Ropi, Citra Perempuan dalam Islam, (Jakarta: PT Gramedia Pustaka Utara, 2003), h. 1. 
Gerakan feminisme ini pada mulanya muncul dari adanya suatu anggapan bahwa terdapat suatu kesalahan masyarakat di dalam memperlakukan perempuan sebagai wujud ketidakadilan gender. Oleh karena itu para feminis berusaha untuk menganalisa sebab-sebab penindasan perempuan dan berusaha untuk memperoleh kebebasan bagi perempuan, memperoleh kesetaraan sosial (social equality) dengan laki-laki dalam segala bidang kehidupan. Berbagai definisi tentang feminisme banyak dikemukakan oleh para ahli diantaranya Kamla Bashin dan Nighat Said Khan yang menyatakan bahwa feminisme ialah suatu kesadaran akan penindasan dan pemerasan terhadap perempuan dalam masyarakat, di tempat kerja dan dalam keluarga, serta tindakan sadar oleh perempuan maupun laki-laki untuk mengubah keadaan tersebut. ${ }^{2}$

Sejalan dengan gerakan feminisme, muncul berbagai teori feminism dan corak gerakannya sebagai akibat adanya berbagai macam pendapat yang bersumber dari beberapa disiplin ilmu.Walaupun sulit untuk mencari titik temu dari beberapa teori feminisme tersebut akan tetapi semua bertolak pada asumsi bahwa ideologi patriarkhi adalah negatif karena telah menempatkan perempuan pada posisi subordinat, yaitu dibawah laki-laki. ${ }^{3}$

\section{Pengertian Gender}

Allah menciptakan bentuk fisik dan tabiat perempuan berbeda dengan pria. Kaum pria di berikan kelebihan oleh Allah baik fisik maupun mental atas kaum perempuan sehingga pantas kaum pria sebagai pemimpin atas kaum perempuan. Allah berfirman: artinya "Kaum lelaki itu adalah sebagai pemimpin (pelindung) bagi kaum perempuan."(QS. al-Nisa': 35 ).

Sehingga secara asal nafkah bagi keluarga itu tanggug jawab kaum lelaki. Asy-Syaikh Ibnu Baaz berkata: "Islam menetapkan masing-masing dari suami istri memiliki kewajiban yang khusus agar keduanya menjalankan perannya, hingga sempurnalah bangunan masyarakat di dalam dan di luar rumah. Suami berkewajiban mencari nafkah dan penghasilan sedangkan istri berkewajiban mendidik anak-anaknya, memberikan kasih sayang,

\footnotetext{
${ }^{2}$ Kamla Bashin dan Nighat Said Khan, Persoalan Pokok Mengenai Feminisme dan Relevansinya, Terj. S. Herlina, (Jakarta: Gramedia, 1995) h. 5.

${ }^{3}$ Mundir, Perempuan dalam al-Quran: Studi Tafsir al-Manar, (Semarang: Walisongo Press, 2010) h. 73-77.
} 
menyusui dan mengasuh mereka serta tugas-tugas lain yang sesuai baginya, mengajar anak-anak perempuan, mengurusi sekolah mereka, dan mengobati mereka serta pekerjaan lain yang khusus bagi kaum perempuan. Bila perempuan sampai meninggalkan kewajiban dalam rumahnya berarti ia menyia-nyiakan rumah berikut penghuninya. Hal tersebut berdampak terpecahnya keluarga baik hakiki maupun maknawi. ${ }^{4}$ Secara umum, pengertian gender adalah perbedaan yang tampak antara laki-laki dan perempuan apabila dilihat dari nilai dan tingkah laku. Sejauh ini persoalan gender lebih didominasi oleh perspektif perempuan, sementara dari perspektif pria sendiri belum begitu banyak dibahas. Dominannya perspektif perempuan sering mengakibatkan jalan buntu dalam mencari solusi yang diharapkan, karena akhirnya berujung pada persoalan yang bersumber dari kaum laki-laki. Ada beberapa fenomena yang sering kali muncul pada persoalan gender.

Kata gender berasal dari bahasa Inggris yang berarti jenis kelamin. ${ }^{5}$ Secara umum, pengertian gender adalah perbedaan yang tampak antara laki-laki dan perempuan apabila dilihat dari nilai dan tingkah laku. Dalam Women Studies Ensiklopedia dijelaskan bahwa gender adalah suatu konsep kultural, berupaya membuat perbedaan (distinction) dalam hal peran, perilaku, mentalitas, dan karakteristik emosional antara laki-laki dan perempuan yang berkembang dalam masyarakat. Dalam buku Sex and Gender yang ditulis oleh Hilary M. Lips mengartikan gender sebagai harapan-harapan budaya terhadap laki-laki dan perempuan. Misalnya; perempuan dikenal dengan lemah lembut, cantik, emosional dan keibuan. Sementara laki-laki dianggap kuat, rasional, jantan dan perkasa. Ciri-ciri dari sifat itu merupakan sifat yang dapat dipertukarkan, misalnya ada laki-laki yang lemah lembut, ada perempuan yang kuat, rasional dan perkasa. Perubahan ciri dari sifat-sifat tersebut dapat terjadi dari waktu ke waktu dan dari tempat ke tempat yang lain. ${ }^{6}$

Heddy Shri Ahimsha Putra (2000) menegasakan bahwa istilah gender dapat dibedakan ke dalam beberapa pengertian berikut ini: gender sebagai

${ }^{4}$ Khatharu Musyarakatil Mar'ah lir Rijal fil Maidanil Amal, h. 5.

${ }_{5}^{5}$ John M. Echols dan Hassan Sadhily, Kamus Inggris - Indonesia, (Jakarta: Gramedia, 1983), h. 256.

6Mansour Faqih, Membincang Feminisme Diskursi Gender Perspektif Islam, (Surabaya: Risalah Gusti, 2000), h. 8-9. 
suatu istilah asing dengan makna tertentu, gender sebagai suatu fenomena sosial budaya, gender sebagai suatu kesadaran sosial, gender sebagai suatu persoalan sosial budaya, gender sebagai sebuah konsep untuk analisis, gender sebagai sebuah perspektif untuk memandang kenyataan. Epistemologi penelitian gender secara garis besar bertitik tolak pada paradigma feminisme yang mengikuti dua teori yaitu; fungsionalisme struktural dan konflik. Aliran fungsionalisme struktural tersebut berangkat dari asumsi bahwa suatu masyarakat terdiri atas berbagai bagian yang saling mempengaruhi.

Teori tersebut mencari unsur-unsur mendasar yang berpengaruh di dalam masyarakat. Teori fungsionalis dan sosiologi secara inhern bersifat konservatif dapat dihubungkan dengan karya-karya August Comte (17981857), Herbert Spencer (1820-1930), dan masih banyak para ilmuwan yang lain. Teori fungsionalis kontemporer memusatkan pada isu-isu mengenai stabilitas sosial dan harmonis. Perubahan sosial dilukiskan sebagai evolusi alamiah yang merupakan respons terhadap ketidakseimbangan antar fungsi sosial dengan struktur peran-peran sosial. Perubahan sosial secara cepat dianggap perubahan disfungsional. Hilary M. Lips dan S. A. Shield membedakan teori strukturalis dan teori fungsionalis. Teori strukturalis condong ke sosiologi, sedangkan teori fungsionalis lebih condong ke psikologis namun keduanya mempunyai kesimpulan yang sama. Dalam teori itu, hubungan antara laki-laki dan perempuan lebih merupakan kelestarian, keharmonisan daripada bentuk persaingan (Talcott Parson dan Robert Bales). Sistem nilai senantiasa bekerja dan berfungsi untuk menciptakan keseimbangan dalam masyarakat, misalnya laki-laki sebagi pemburu dan perempuan sebagai peramu. Perempuan dengan fungsi reproduksinya menuntut untuk berada pada peran domestik. Sedangkan laki-laki pemegang peran publik. Dalam masyarakat seperti itu, stratifikasi peran gender ditentukan oleh jenis kelamin (sex).

Kritik terhadap aliran tersebut bahwa struktur keluarga kecil yang menjadi ciri khas keluarga modern menyebabkan perubahan dalam masyarakat. Jika dulu tugas dan tanggung jawab keluarga besar dipikul bersama-sama, dewasa ini fungsi tersebut tidak selalu dapat dilakukan. Sedangkan teori konflik diidentikkan dengan teori marxis karena bersumber pada tulisan dan pikiran Karl Marx. Menurut teori itu, perubahan sosial, terjadi melalui proses dialektika. Teori itu berasumsi bahwa dalam susunan masyarakat terdapat beberapa kelas yang saling memperebutkan pengaruh dan kekuasaan. 
Friedrich Engels, melengkapi pendapat Marx bahwa perbedaan dan ketimpangan gender tidak disebabkan oleh perbedaan jenis kelamin (biologis), akan tetapi merupakan divine creation. Engels memandang masyarakat primitif lebih bersikap egaliter karena ketika itu belum dikenal adanya surplus penghasilan. Mereka hidup secara nomaden sehingga belum dikenal adanya pemilikan secara pribadi. Rumah tangga dibangun atas peran komunitas. Perempuan memiliki peran dan kontribusi yang sama dengan laki-laki.

Menurut Marxisme, penindasan perempuan dalam dunia kapitalis karena mendatangkan keuntungan. Pertama, eksploitasi perempuan dalam rumah tangga akan meningkatkan meningkatkan produksi kerja laki-laki di pabrik-pabrik. Kedua, perempuan yang terlibat peran produksi menjadi buruh murah, memungkinkan dapat menekan biaya produksi, sehingga perusahaan lebih diuntungkan. Ketiga, masuknya perempuan sebagai buruh murah dan mengkondisikan buruh-buruh cadangan akan memperkuat posisi tawar pihak kapitalis, mengancam solidaritas kaum buruh. Ketiga, hal tersebut dapat mempercepat akumulasi kapital bagi kapitalis. ${ }^{7}$ Sedangkan Dahrendarf dan Randall Collins tidak sepenuhnya sependapat dengan Marx dan Engels. Menurutnya konflik tidak hanya terjadi pada perjuangan pekerja kepada pemilik modal, tetapi juga disebabkan oleh faktor kesenjangan antara anak dan orang tua, istri dengan suami, yunior dengan senior dan sebagainya. ${ }^{8}$

\section{Pemikiran Feminis Islam}

Gerakan feminisme dalam Islam sebenarnya timbul karena pengaruh pemikiran-pemikiran dari luar yang mempunyai tujuan tertentu karena jauh sebelum gerakan feminis muncul, Islam telah mengatur kehidupan, gerak perempuan, yang dijelaskan dalam hadits-hadits Rasulullah bagaimana kehidupan perempuan pada masa itu, bagaimana interaksi sosialnya.

Islam datang memberikan kedudukan penting baik dalam undangundang maupun dalam persamaan hak dengan kaum laki-laki, jadi tidak ada diskriminasi bagi perempuan. Kesamaan hak dalam Islam diatur secara jelas dalam al-Qur'an yang terbagi dalam beberapa bagian, yaitu:

\footnotetext{
7 Ibid, h. 87-88.

${ }^{8}$ https://docs.google.com/document/d/1S_sPIU0eOMcmx6dOEimZRjAgGAn8NEU1x5 mqyG3Fu20/edit?hl=in\&pli=1/13/09/2013.
} 
1. Kesamaan dalam hak asal penciptaan.

Hal ini sesuai dengan yang tercantum dalam QS. al-A'raf ayat 189:

"Dan Dialah yang menciptakan kamu dari jiwa yang satu (Adam) dan dari padanya Dia menciptakan pasanganya, agar dia merasa senang kepadanya..". Jadi berdasarkan ayat diatas, perempuan dan laki-laki diciptakan dari bahan yang sama dan dari keduanya terlahir dari apa yang Allah ciptakan yaitu Adam dan Hawa.

2. Kesamaan dalam hal taklif dan pahala.

Islam menyamakan laki-laki dan perempuan di hadapan syariat dan pahala tanpa ada diskriminasi, hal ini sebagaimana yang tercantum dalam QS. al-Nisa ayat 124: "Dan barang siapa mengerjakan kebajikan, baik laki-laki maupun perempuan sedang dia beriman, maka mereka akan masuk kedalam surga dan mereka tidak didzalimi sedikit pun".

3. Kesamaan dalam hal hudud dan sanksi Syariat

Sebagai contohnya adalah sanksi bagi orang yang melakukan zina itu terdapat dalam QS. al-Nur ayat 2. "Perempuan yang berzina dan laki-laki yang berzina, maka deralah tiap-tiap seorang dari keduanya seratus kali dera, dan janganlah belas kasihan kepada keduanya mencegah kamu untuk (menjalankan) agama Allah, jika kamu beriman kepada Allah, dan hari akhirat, dan hendaklah (pelaksanaan) hukuman mereka disaksikan oleh sekumpulan dari orang-orang yang beriman". Dalam ayat tersebut dijelaskan bahwa orang yang berzina harus di hukum sesuai ketentuan tidak membedakan antara laki-laki dan perempuan.

4. Persamaan dalam hak menggunakan harta dan kepemilikan harta.

Setiap laki-laki dan perempuan yang telah baligh dan berakal memiliki hak secara hukum untuk menggunakan apa yang dia miliki secara bebas, seperti dalam hal menjual, hibah, wasiat, sewa menyewa mewakilkan pada orang.

Dengan demikian jelaslah bahwa Islam tidak membedakan hak-hak perempuan terhadap laki-laki, memang ada kekhususan hukum yang berlaku bagi perempuan dan tidak berlaku bagi laki-laki. Kajian mengenai isu gender dalam Islam mengalami perkembangan yang cukup signifikan, hal ini ditandai tidak saja melimpahnya publikasi yang mengangkat wacana gender dan Islam, melainkan juga fakta bahwa ia sudah merambah luas kedalam suatu mainstream gerakan yang kemudian mengundang orang 
untuk dengan mudah menyebutnya sebagai "gerakan feminisme Islam". Meskipun definisi feminisme Islam itu sendiri masih menjadi perdebatan serius dikalangan aktifis perempuan muslim, pada tingkatan common vision mereka dapat bertemu pada suatu visi misi untuk memperjuangkan keadilan dan kesetaraan gender. ${ }^{9}$

Seperti yang telah disampaikan sebelumnya bahwa kini isu feminisme mulai masuk ke wilayah Islam, banyak cendekiawan muslim yang melihatnya sebagai pendekatan baru dalam studi Islam. Istilah feminis muslim mulai diperkenalkan dan digunakan pada tahun 1990-an, diantara tokohtokoh yang pernah menggunakan istilah tersebut adalah Afsaneh Najmabedeh dan Ziba Mir-Hosseini dari Tehran, Yesim Arat dari Turki, serta Mai Yamani dari Saudi Arabia melalui bukunya "Feminisme and Islam" yang diterbitkan pada tahun 1996. Sedangkan Mesir yang dikatakan sebagai tempat terlahirnya feminis muslim terkenal dengan tokohnya Huda Shaarawi yang mendirikan The Egyption Feminis Union pada tahun 1923, pada dasarnya asa dan pemikiran mereka sama dengan feminis Barat. Namun demikian, tidak semua secara terbuka merasa nyaman menisbahkan atau mengaitkan diri mereka dengan perjuangan feminis Muslim.

Prioritas misi kebanyakan kaum feminis muslim adalah:

1. Merekonstruksi hukum-hukum agama berkaitan dengan menilai dan menganalisa ulang teks agama, al-Qura'an dan as-Sunnah, serta menafsirkannya dari perspektif yang berbeda dengan penafsiran klasik (ijtihad dan tafsir). Feminis muslim mendakwa bahwa prinsip keadilan dan kesetaraan yang ditekankan oleh al-Qur'an tidak terlaksana disebabkan para mufassirin yang umumnya kaum pria, mereka telah menghasilkan tafsir al-Qur'an yang mendukung doktrin yang mengangkat martabat kaum pria dan menjustifikasi superioritas kaum pria.

2. Feminis muslim juga berpendapat bahwa terdapat bias gender yang kental dalam hukum-hukum syariah yang diambil dari hadist-hadist Rasulullah SAW, atas alasan perawi hadist yang terdiri dari kalangan sahabat adalah pria yang tidak dapat membebaskan diri dari pengaruh amalan patriarki. Pada praktiknya feminis muslim justru bertindak antagonis terhadap beberapa hukum dalam al-Qur'an yang berkaitan dengan perempuan.

9Jamhari Ismatu Ropi, Citra Perempuan dalam Islam, h. 1. 


\section{E. Pengertian dan Ruang Lingkup Pemikiran Feminis Barat}

Paham feminisme barat (sekuler) bermula dari aktifis perempuan barat yang merasa tertindas oleh ideologi gereja, tidak bisa dipungkiri ajaran gereja pada abad ke-17 dan 18 tidak memberi tempat yang adil terhadap perempuan bahkan berlaku kejam. Keyakinan seperti itu tentu saja mempengaruhi cara pandang manusia Barat terhadap perempuan, pada abad pertengahan perempuan Eropa tidak memiliki hak kekayaan, hak belajar dan turut serta dalam partisipasi politik. Bahkan di Jerman suami boleh menjual istrinya, perempuan benar-benar dinista bagaikan barang, seorang ibu dilarang mendidik anaknya kecuali ada izin dari suami.

Gerakan pembebasan pada enlightenmen menjadi momentum penting bagi kaum pembela perempuan, abad ke-17 bisa dikatakan gerakan pembebasan bernama feminisme itu mendapat dukungan secara luas, muncul tokoh-tokoh perempuan yang menentang otoritas agama dan tradisi kuno patriarki. Marry Wollstonecraft disebut-sebut sebagai perempuan Barat yang paling terdepan melawan misoginisme, ia kemudian diikuti oleh perempuan liberal lainnya, seperti Hellence Brion dari Perancis, Clara Zektin dari Jerman, Anna Kuliscioff dari Italia. ${ }^{10}$ Meski gerakan ini mendapat dukungan luas dari para aktifis perempuan dari negara-negara Eropa, namun gerakan feminisme yang menjadikan enlightenmen sebagai kendaraan tidak terlalu menyatu dengan gerakan para filsuf.

Negara barat mempunyai ideologi yang berbeda-beda, sehingga aliranaliran feminisme yang berkembang disetiap negara barat berbeda-beda pula, aliran-aliran atau gerakan-gerakannya adalah sebagai berikut:

\section{Feminisme Sosial}

Gerakan feminisme sosialis adalah gerakan feminisme yang mengadopsi teori Praxis Marxisme, yakni teori penyadaran pada kelompok tertindas agar para perempuan sadar bahwa mereka merupakan kelas yang tidak diuntungkan. Penyebab penindasan perempuan dihubungkan dengan tipe organisasi sosial, khususnya tatanan perekonomian.

Timbulnya penyadaran ini akan membuat para perempuan bangkit emosinya, dan secara kelompok diharapkan untuk mengadakan konflik

\footnotetext{
${ }^{10}$ Arif Syamsuddin, Orientalis dan Diabolisme Pemikiran, (Jakarta: Gema Insani Press, 2008), h. 106.
} 
langsung dengan kelompok (laki-laki). Semakin tinggi tingkat konflik dominasi, diharapkan dapat meruntuhkan sistem patriarki.

\section{Feminisme Radikal}

Teori feminisme radikal berkembang pesat di Amerika Serikat pada kurun waktu 1960-an sampai 1970-an, feminisme radikal lebih memfokuskan serangannya pada keberadaan institusi keluarga dan sistem patriarki. Lembaga perkawinan adalah lembaga formalitas untuk menindas perempuan, sehingga tugas utama para radikal feminis adalah menolak institusi keluarga. ${ }^{11}$ Feminisme radikal cenderung membenci laki-laki sebagai individu dan mengajak perempuan untuk mandiri, bahkan tanpa perlu keberadaan laki-laki dalam kehidupan perempuan.

\section{Feminisme Liberal}

Feminisme liberalisme berasumsi bahwa pada dasarnya tidak ada perbedaan antara laki-laki dan perempuan, feminisme liberalisme lebih memfokuskan pad perubahan undang-undang yang menempatkan suami sebagai kepala keluarga.Konsep kepala keluarga konvensional yang berlaku secara universal adalah suami sebagai pemberi nafkah dan pelindung keluarga. Hal ini menurut feminisme liberal tidak sesuai dengan konsep kebebasan individu untuk mandiri dan menentukan jalan mereka sendiri, konsep kepala keluarga ini menurut mereka dapat membuat perempuan terus tergantung pada laki-laki.

\section{Teologi Feminisme}

Teori feminisme bersumber dari madzhab teologi pembebasan yang dikembangkan oleh James Cone diakhir 1960-an, teori pembebasan yang diterapkan pada perempuan yang dianggap tertindas disebut teologi feminisme. Teologi feminisme ini berkembang pada berbagai agama seperti Kristen, Yahudi, dan Islam.

Menurut para feminisme, agama-agama tersebut sering ditafsirkan dengan memakai ideologi patriarki dan menyudutkan perempuan. Isu-isu yang sering dipermasalahkan adalah tentang penciptaan Adam dan Hawa dan kepemipinan perempuan dalam agama, misalnya menolak penafsiran bahwa Hawa diciptakan dari tulang rusuk Adam.

${ }^{11}$ Mansour Faqih, Membincang Feminisme Diskursi Gender Perspektif Islam, h. 209-210. 


\section{Feminisme Kultural}

Feminisme kultural menekankan pentingnya gaya hidup yang berciri perempuan. Feminisme ini tidak berkecenderungan kepada pembentukan kembali masyarakat ataupun perubahan masyarakat, akan tetapi memusatkan perhatian kepada pemecahan persoalan-persoalan individu dan menciptakan alternatif-alternatif bagi gerakan sosial. Berbeda dengan teori feminisme lainnya feminisme kultural tidak menolak perbedaan biologis laki-laki dan perempuan, atau menganggap perbedaan itu sebagai penindasan perempuan. Diantara tokoh dalam Feminisme kultural ini adalah Mary Daly, Andirenne dan Sussan Griffin.

\section{Ekofeminisme}

Ekofeminisme adalah visi baru gerakan feminisme. Teori ini adalah teori feminisme yang konsepnya bertolak belakang dengan feminisme modern (feminisme sosial, radikal dan liberal) yang telah mewarnai gerakan feminisme semenjak awal abad ke-20 sampai akhir tahun 1970-an di Barat, tetapi memiliki kesamaan dengan feminisme kultural dalam memandangkan relasi gender. Baik ekofeminisme maupun feminisme kultural, keduanya memandang perbedaan gender bukan semata-mata konstruksi sosial, tetapi juga bersifat fitrah. ${ }^{12}$

\section{F. Relevansi Pemikiran Feminis Islam dan Pemikiran Feminis Barat}

Sudah dijelaskan diatas bahwa didalam Islam tidak ada perbedaan hak dan tidak ada penindasan terhadap perempuan oleh kaum laki-laki, akan tetepi perlu diketahui bahwa antara laki-laki dan perempuan ada perbedaan baik secara biologis maupun naluri diakui atau tidak, mau ataupun tidak menafsirkan syariat Islam. Feminisme juga dijadikan sebagai alat analisis yang dapat menghadirkan kesadaran baik laki-laki ataupun perempuan sendiri. Berbeda dengan aliran feminisme yang ada di Barat, yang dipengaruhi ideologi yang berkembang sehingga melahirkan aliran fanatik terhadap suatu ideologi sebagaimana yang kita lihat dalam pembagian aliran feminisme barat yang telah diuraikan diatas, karena memang yang menjadi dasar ideologi agama Islam adalah al-Qur'an dan Hadist sehingga

${ }^{12}$ Mundir, Perempuan dalam al-Quran: Studi Tafsir al-Manar, h. 54-55. 
tidak ada aliran-aliran feminisme sebagaimana di Barat. Akan tetapi memang di beberapa Negara Islam ada sebuah gerakan misalnya di Mesir, Turki, Pakistan yang bertujuan untuk memperjuangkan hak-hak perempuan yang tidak bertentangan dengan syariat Islam, misalnya hak mendapatkan pendidikan, kiprahnya dalam bidang sosial, bidang agama ini terjadi pada abad ke-19.

Perempuan adalah setengah masyarakat, jika kaum perempuan tidak berfungsi berarti separuh kehidupan manusia tidak berfungsi. Perempuan juga mempunyai pengaruh yang luar biasa melebihi jumlahnya jika perempuan tidak diberikan kebebasanya untuk menjalankan fungsinya maka perempuan juga tidak bisa melakukan kewajiban-kewajibanya semaksimal mungkin, untuk mewujudkan fungsi separuh masyarakat dalam kategori masyarakat yang baik maka perempuan mempunyai kewajiban yang harus dipenuhi antara lain:

1. Kewajiban terhadap agama, yang dimaksud adalah kewajiban untuk membuktikan ketinggian Islam diatas nilai ideologi dan tatanan hidup lainya dengan cara:memiliki akhlakul karimah, meningkatkan ilmu dan kecerdasan serta memperbanyak amal, gerak, dan perjuangan yang baik.

2. Kewajiban terhadap pribadinya, yang dimaksud adalah kewajiban yang harus dipenuh terhadap diri sendiri agar kualitas pribadinya semakin baik hal ini menyangkut dengan jasmani dan rohani. Adapun kewajiban jasmani diwujudkan dengan cara menjaga kesehatan diri, keluarga serta lingkungan sedangkan kewajiban rohani diwujudkan dengan cara membersihkan hati dari sifat-sifat tercela.

3. Kewajiban terhadap rumah tangga, yang dimaksud adalah kewajiban yang harus dilaksanakan terhadap rumah tangga. Dalam hal ini perempuan harus mempunyai pengetahuan yang banyak untuk menjalankan peran dalam rumah tangga sebagai ibu dari anak-anaknya, sebagai teman hidup serta sebagai penenang suami dalam hidup.

4. Kewajiban terhadap masyarakatnya, maksudnya adalah kewajiban yang harus dipenuhi terhadap masyarakat. Artinya mempunyai peran dalam kehidupan sosial, perempuan harus berperan aktif dalam berinteraksi sosial dengan orang lain sesuai dengan kodratnya misalnya aktif dalam bidang pendidikan, organisasi sosial penting antara lain: mem-permudah urusan hidup, membangun kepribadian perempuan, menuntut ilmu, 
berbuat baik, beramar ma'ruf nahi munkar, menyeru agama, berjihad di jalan Allah, melaksanakan kegiatan profesi dan lain-lain.

5. Kewajiban terhadap negara atau tanah air, perempuan menjadi bagian dalam mewujudkan negara, tanah air, dan bangsa yang Islami baik melalui tumbuhnya masyarakat Islam sampai peperangan terhadap kaum kafir dan mempertahankan peraturan-peraturan Islam.

Agama-agama di dunia memiliki peran dan prinsip-prinsip yang hampir sama, tentang keharusan kaum perempuan yang harus mengikuti kaum laki-laki dimana konsep patriarki itu tumbuh. Banyak klaim dan dalil-dalil yang diduga berasal dari Tuhan, maskulin yang menetapkan nilai klasifikasi serta kekuasaan laki-laki didalam rumah tangga maupun lingkungan sosial masyarakat. Kaum laki-laki lebih kuat atau berkuasa daripada kaum perempuan, bahkan perempuan diciptakan dari bagian tubuh kaum lakilaki. Perempuan bukanlah makhluk lemah kualitasnya dibandingkan kaum laki-laki, sebagaimana diasumsikan banyak orang. Bahkan sejarah telah berbicara kepada kita bahwa perempuan telah memberikan sumbangsih intelektual pertama dalam peradaban dunia, perempuan lebih dahulu berpikir dengan akalnya dibandingkan kaum laki-laki. Dialah (Hawa) kaum perempuan yang menjadi pelopor pembangunan ilmu pengetahuan dan peradaban dunia dalam sejarah kemanusiaan.

Menurut Nawal El-Saadawi kaum perempuan tidak akan terbebaskan dari sistem patriarki kecuali dari diri mereka sendiri yang mulai merubahnya dan berusaha untuk mengangkat harkat dan martabatnya dengan mengusung gagasan perubahan dan modernisasi. Perempuan haruslah kuat dimulai dari pribadinya masing-masing, menurut beliau perempuan harus bisa terbebaskan dan berani menyikap tabir pikiran mereka, yaitu kesadaran palsu, kesan-kesan minor, dan sikap lemah yang selama ini melekat pada kaum perempuan. Sehingga nantinya akan muncul sebuah kesadaran baru pada diri mereka bahwa sesungguhnya tidak ada perbedaan berarti antara dirinya dan kaum lelaki. Setelah itu mereka akan menjadi suatu kekuatan politik yang memiliki otoritas dalam mengambil keputusan yang besar, semua ini akan terwujud melalui organisasi keperempuanan yang sadar akan hak-hak dan tujuan. ${ }^{13}$

\footnotetext{
${ }^{13} \mathrm{http}: / /$ ukonpurkonudin.blogspot.com/2011/09/pemikiran-feminisme-nawal-elsaadawi.html/14/09/2013.
} 


\section{G. Kesimpulan}

Kesimpulan dari makalah ini adalah bahwa pada dasarnya antara lakilaki dan perempuan mempunyai perbedaan yang dianggap sebagai penindasan, diskriminasi menurut versi perempuan barat. Dengan pandangan yang seperti itu perempuan barat menuntut dan meperjuangkan persamaan untuk menghilangkan perbedaan melalui pembentukan gerakangerakan feminis antara lain Sosialis, Radikal, Liberal, Teologi Feminisme, Kultural. Dalam pandangan Islam feminisme bukanlah sebuah cara untuk memperbaiki keadaan perempuan akan tetapi Islam telah mengatur, telah menjelaskan secara jelas kedudukan, peran dan fungsi perempuan dalam keluarga, masyarakat dan negara. Gugatan yang dilancarkan oleh gerakan feminisme pada intinya dilakukan oleh perempuan yang kurang tahu tentang hak dan kewajiban yang sudah diatur dalam ajaran Islam. Dan bagi perempuan yang sudah mempelajari serta mendalami ajaran Islam dengan baik dan benar mereka malah bersyukur karena ajaran Islam telah mengatur hak dan kewajiban perempuan secara rinci dan jelas.

Dan pada dasarnya antara laki-laki dan perempuan merupakan dua unsur yang saling membutuhkan satu sama lain, saling mengisi saling melengkapi, kalau toh ingin kesamaan Islam telah mengaturnya kapan lakilaki dan perempuan sama dan kapan secara hukum berbeda.[]

\section{Daftar Pustaka}

Bashin, Kamla dan Nighat Said Khan, Persoalan Pokok Mengenai Feminisme dan Relevansinya, Terj. S. Herlina, Jakarta: Gramedia, 1995.

Faqih, Mansour, Membincang Feminisme Diskursi Gender Perspektif Islam, Surabaya: Risalah Gusti, 2000.

http://ukonpurkonudin.blogspot.com/2011/09/pemikiran-feminisme-nawal-el saadawi.html/14/09/2013.

https://docs.google.com/document/d/1S_sPIU0eOMcmx6dOEimZRjAgGAn 8NEU1x5mqyG3Fu20/edit?hl=in\&pli=1/13/09/2013.

Mundir, Perempuan dalam al-Qur'an (Studi Tafsir al-Manar), Semarang: Walisongo Press, 2010. 
Ropi, Jamhari Ismatu, Citra Perempuan Dalam Islam, Jakarta: PT Gramedia Pustaka Utara, 2003.

Syamsuddin, Arif, Orientalis dan Diabolisme Pemikiran, Jakarta: Gema Insani Press, 2008. 
